\title{
The role of advocacy in promoting better child health
}

Authors

Delan Devakumar, Institute of Epidemiology and Health Care, University College London,

London, UK

Nick Spencer, Division of Mental Health and Wellbeing, Warwick Medical School, Coventry,

UK

Tony Waterston, Retired paediatrician

Corresponding author

Dr Delan Devakumar

Institute of Epidemiology and Health

University College London

Mortimer Market Centre

London, WC1E 6JB

d.devakumar@ucl.ac.uk

Tel: 02031082078

Keywords

Advocacy, children's rights. 


\section{SUMMARY}

Child health professionals play a crucial role in advocating for children and it is incumbent on all who work with them to observe and enforce the maintenance of childrens' rights. In this article we summarise what advocacy is, its importance for child health and briefly how to go about it. Finally, we provide three differing examples of how advocacy has been used to improve the health of children.

\section{INTRODUCTION}

Despite the many recent gains in child health, approximately six million children still die worldwide of mostly preventable causes. Mortality rates in the poorest countries are orders of magnitude higher than the richest and inequalities in health are also profound within the same country, as the richest groups across countries have similar health outcomes. ${ }^{1}$ The causes are numerous and include birth-related conditions, infectious disease, malnutrition, and increasingly non-communicable diseases. In addition to these, children have always been, and sadly will continue to be, victims of abuse. This may take active forms, such as physical or sexual violence, or passive forms, such as neglect.

As child health specialists, we have a duty of care to our patients to help manage their diseases, but we also have a role in preventing these diseases from arising in the first place. Advocacy is important in both these respects, speaking out for unwell children but also in attempting to deal with determinants of health that underpin the biomedical causes, in the communities in which they live. Achieving optimum child health however, is much more than this, it is seeking a state of wellbeing where a child is able to grow and develop, while nurtured and protected.

As a potentially vulnerable group in society, children require others to support their voice or advocate on their behalf. This matters because the differences in health outcomes are generally preventable and are inequities, i.e. are unfair, rather than purely inequalities. ${ }^{23}$

Children do not have political power or a democratic voice, and generally have actions done 
to them, often without their consent. Without others advocating for a child, powerful organisations can act in their own best interests, which may work against the health and wellbeing of children. An example of this would be the marketing of high sugar content foods and drinks by companies to children leading to illnesses such as tooth decay and contributing to obesity. ${ }^{4}$ In this article we call on child health specialists to advocate on behalf of the children they see and the population more broadly. This can be done individually or as part of coalitions.

\section{WHAT IS ADVOCACY?}

Advocacy can be defined as "speaking out on behalf of a particular issue, idea or person", acting as a catalyst for change. ${ }^{5}$ Advocates draw attention to issues, raise the profile of issues that need to be addressed and, when required, challenge authorities. In this context, child advocates are individuals working by themselves or within organisations that protect and advance a child's interests in relation to their health.

An approach to advocacy is to focus on the rights of the child. As citizens of a society, each child assumes rights that should be upheld, independent to their parents. It is therefore not out of charity that we act to help children, rather it is an imperative. In addition to the civil and political rights that children possess, they also have a number of economic, social and cultural rights. The United Nations Convention on the Rights of the Child (UNCRC) clearly sets out 54 articles that describe these multi-faceted goals, including eight for how governments and adults can make sure the rights are upheld. All countries in the world, with the exception of one, have ratified this convention. Ratification however is not enough, as countries need a strategy that outlines the way in which the articles can be met. Child rights can be incorporated into country law, and many have done this, at least partially. Others, such as Wales, have introduced compulsory assessment and monitoring of new policies that they comply with the UNCRC. Legal challenges though are not easy or cheap, so practically court cases are rare, but the UNCRC does serve as a normative standard and helps to push a society 
to towards greater rights for children. Importantly, the rights can be used by individuals or organisations to argue for provisions to improve child health. A good example of a broader, system-wide approach is the application of the UNCRC to a location, to produce a Child Friendly Cities. Here the standards of the convention are applied to the political, social and physical environment to increase the health and life chances for children. ${ }^{6}$

Advocacy is usually the result of the combination of many actors and actions, so attribution to any particular intervention is not easy and measuring the impact of advocacy is difficult. Advocacy evaluation however is a field of growing importance and should be attempted wherever possible. An example of this was the campaign to reduce salt by the Australian World Action on Salt and Health. Stakeholder analysis showed that the campaign had influenced policy but causality was still uncertain. ${ }^{7}$ Wherever possible both interim outputs and outcomes should be measured, for example the Harvard Family Research Project has produced a guide to measuring advocacy and policy that describes different aspects of advocacy and possible indicators that might be measured. ${ }^{8}$ This involves planning to ensure that data on the appropriate indicators are collected and adequate funding of advocacy to enable evidence and rights based policy creation and practice. ${ }^{9}$

\section{WHO CAN ADVOCATE?}

Anyone can act as an advocate, but paediatricians and child health specialists have a special role in this. Advocating for an individual child is usually the role of the parent or guardian but they may be unable or unwilling, and occasionally a child's rights are in conflict with their parents. Advocating for a population tends to be the responsibility of the government, some non-governmental organisations and public health practitioners. Child health professionals have an important role, straddling these two scenarios. As respected, independent professionals, paediatricians have power, which stems from their authority on the subject of child health, and often medical staff are the only ones with the access and expertise to identify problems. 
Paediatricians are aware of their duties in child protection, but this is only one end of the spectrum. Advocacy will naturally be aimed at helping vulnerable children, but it also about helping the entire population using a public health approach taking into consideration the children who are not seen. Most healthcare professionals work at the level of the child or children they see (the micro level) and advocate for improvements in the treatment of these children. Advocacy also goes much further attending to the "macro" upstream determinants of health that may cause illness by acting through factors such as the environment, education, violence and social capital.

When coordinated in national and international paediatric bodies and societies, collectively this enables child health professionals to work more effectively and potentially influence policy change. An example would be the American Academy of Pediatrics' strategic plan to reduce the impact of poverty on child health through advocating for policies that reduce the number of families in poverty and its adverse effects, supporting paediatricians, research, raising awareness and developing strategies to work with community partners to address the impact of poverty. ${ }^{10}$

\section{HOW DO WE ADVOCATE FOR A CHILD/CHILDREN?}

It is not possible here to provide a step-by-step guide to advocacy, but comprehensive summaries do exist, for example that produced by Save the Children. ${ }^{11}$ We will summarise some of the key stages, as shown in Figure 1, the Advocacy Cycle.

Advocacy is primarily about supporting children in the important health and disease-related decisions in their lives. The first step therefore is to listen to the views of children and their parents and, as specified in article 12 of the UNCRC, wherever possible children should be involved in decisions relating to their care. Clear, and ideally achievable "SMART", goals should then be set. An example of this would be the engagement work done by the Council for Disabled Children to ensure that the voices of disabled children and young people are heard and inform policy. ${ }^{12}$ 
Child health specialists need to be willing to speak out and actively take on this responsibility. This starts with them learning about what rights children possess and potentially performing a rights-based situation analysis. Equally they require knowledge of the ways in which the UNCRC is upheld in the location in which they reside. Even brief training can achieve a lot in that it increases understanding and enables practitioners to have to the tools to advocate for children. ${ }^{13}$ In the UK, it can be helpful to work alongside or take advice from the Children's Commissioner. Initially established in the Children Act 2004, they have a statutory duty to promote and protect the rights of children, including health.

Child health professionals must work to pull the levers of power at a local and national level. The practicalities of this will vary from one location to another but an early step is to identify the important stakeholders and the political environment which they are in. Particularly important are those who have the power to propagate or curtail an action. The channel for advocacy again is context specific. Using the media can be helpful in some circumstances and detrimental in others. It may be beneficial to work alongside others in this. In some circumstances, child health professionals may be able to influence that change on their own, but generally others will make the decisions. To make sizeable and sustained improvements will require multi-agency working, for example with the legal and education professions, on the determinants of child health. Here paediatricians can act as health experts contributing to a larger debate using their knowledge of the evidence. A good example of this is advocacy on the harms of second-hand smoke that led to legislation banning smoking in cars when children are present. ${ }^{14} 15$

Finally it is important to monitor and evaluate the effectiveness of any programme undertaken. In Table 1 we provide examples in which advocacy has been successful, including an individual case, a population approach and an example including the role of industry. 


\begin{tabular}{|c|c|c|}
\hline & Description of case & Advocacy \\
\hline $\begin{array}{l}\text { Individual case } \\
\text { requiring } \\
\text { advocacy }\end{array}$ & $\begin{array}{l}\text { Samir (8) is an asylum seeker from } \\
\text { Afghanistan. He lives with his mother and } \\
\text { two siblings in the UK. His father is } \\
\text { imprisoned in Afghanistan owing to his } \\
\text { political activity. } \\
\text { Samir has delayed development (limited } \\
\text { speech, bedwetting, learning difficulties) } \\
\text { since birth of unknown cause. In addition, } \\
\text { he has been showing aggressive behaviour } \\
\text { in the last few months- oppositional, } \\
\text { hitting out at home and at school, running } \\
\text { away when out of the house and a } \\
\text { reluctance to go to school. } \\
\text { He is currently being assessed for transfer } \\
\text { from mainstream to special education } \\
\text { owing to his learning difficulties. During } \\
\text { the assessment the following background } \\
\text { factors emerged: } \\
\text { - His mother's application for } \\
\text { refugee status has been turned } \\
\text { down and she is liable for } \\
\text { deportation } \\
\text { Their council house is in a poor } \\
\text { state and the heating is } \\
\text { inadequate. She has been told she } \\
\text { cannot be re-housed owing to her } \\
\text { asylum seeker status } \\
\text { The family is living on a low } \\
\text { income and will not be able to } \\
\text { claim disability benefit owing to } \\
\text { their asylum seeker status } \\
\text { Samir's siblings (a sister of } 11 \text { and brother } \\
\text { of } 4 \text { ) are not as yet adversely affected by } \\
\text { these problems but the girl is about to start } \\
\text { secondary school and is anxious about } \\
\text { being bullied. } \\
\text { been pourhood and graffiti has } \\
\text { - }\end{array}$ & $\begin{array}{l}\text { Samir's paediatrician used articles } \\
2,19,22,23 \text { and } 27 \text { of the UNCRC } \\
\text { to advocate on Samir's behalf in the } \\
\text { following ways: } \\
\text { - Supported the process to } \\
\text { enter a special school. This } \\
\text { was achieved and his } \\
\text { education and general } \\
\text { wellbeing improved } \\
\text { hugely. } \\
\text { Ensured the involvement of } \\
\text { social services, housing, } \\
\text { local councillors and police } \\
\text { in relation to the } \\
\text { neighbourhood harassment. } \\
\text { Eventually the family were } \\
\text { rehoused after considerable } \\
\text { support from local police. } \\
\text { Requested the MP to } \\
\text { protest the deportation } \\
\text { order and seek refugee } \\
\text { status. The MP became } \\
\text { closely involved and wrote } \\
\text { to the Home secretary. The } \\
\text { deportation was rescinded } \\
\text { and the family was given } \\
\text { refugee status. } \\
\text { Samir's behavioural difficulties } \\
\text { resolved completely and he made } \\
\text { good progress at his special school. }\end{array}$ \\
\hline $\begin{array}{l}\text { Austerity } \\
\text { measures on } \\
\text { families with } \\
\text { disabled children: } \\
\text { survey of the } \\
\text { British } \\
\text { Association for } \\
\text { Community } \\
\text { Child Health } \\
\text { (BACCH) and } \\
\text { British Academy } \\
\text { of Childhood } \\
\text { Disability } \\
\text { (BACD) }\end{array}$ & $\begin{array}{l}\text { A report published by Contact a Family, } \\
\text { entitled Counting the Cost, showed a } \\
\text { sharp rise in families with disabled } \\
\text { children going without basics such as } \\
\text { food, heating and days out as a family in } \\
\text { the previous two years. }{ }^{16} \text { BACCH and } \\
\text { BACD undertook a survey of its members } \\
\text { to gain a professional perspective on the } \\
\text { impact of austerity on children attending } \\
\text { their services. }{ }^{17} \\
\text { The results showed that almost } 80 \% \text { of } \\
\text { those who completed the survey reported } \\
\text { cuts to services for disabled children and } \\
\text { their families and over } 80 \% \text { of }\end{array}$ & $\begin{array}{l}\text { The survey results were reported in } \\
\text { the media, including an interview } \\
\text { with the BACD chair by the BBC. } \\
\text { They strongly urged actors with } \\
\text { influence to: } \\
\text { - Stop the cuts to services for } \\
\text { disabled children and young people. } \\
\text { - Mandate prospective clinical data } \\
\text { capture and build into the Children } \\
\text { and Young People's Secondary } \\
\text { Uses Dataset. This allows the } \\
\text { multi-faceted needs of disabled } \\
\text { children and young people to be } \\
\text { clearly articulated and visible. }\end{array}$ \\
\hline
\end{tabular}




\begin{tabular}{|c|c|c|}
\hline $\begin{array}{l}\text { members and } \\
\text { child } \\
\text { development } \\
\text { team leads }\end{array}$ & $\begin{array}{l}\text { paediatricians were asked to write letters } \\
\text { of advocacy, mostly about housing and } \\
\text { the impact of the bedroom tax. They were } \\
\text { asked about downgrading in the level of } \\
\text { Disability Living Allowance awarded and } \\
\text { other issues, including seeking charitable } \\
\text { funding for equipment or services that } \\
\text { were previously provided. }\end{array}$ & $\begin{array}{l}\text { Knowledge of population needs can } \\
\text { inform intelligent planning across } \\
\text { agencies for evidence-based } \\
\text { services to best meet their needs. } \\
\text { - Reinvest and rebuild competent, } \\
\text { inter-agency teams to prevent } \\
\text { disabling conditions where possible } \\
\text { and where it is not, to identify them } \\
\text { early so that appropriate } \\
\text { management and support can be put } \\
\text { in place, informing and engaging } \\
\text { with families. Sufficient capacity is } \\
\text { needed to meet the increasingly } \\
\text { complex needs of all disabled } \\
\text { children and young people equally, } \\
\text { giving them the best chance of } \\
\text { achieving the best possible } \\
\text { outcomes in health, wellbeing and } \\
\text { life opportunities that matter to } \\
\text { them. } \\
\text { This is an example of members of a } \\
\text { clinical specialist group combining } \\
\text { to record the impact on their patient } \\
\text { group of government policy } \\
\text { decisions. The survey not only } \\
\text { recorded the situation but provided } \\
\text { ammunition for further advocacy } \\
\text { on behalf of disabled children. }\end{array}$ \\
\hline $\begin{array}{l}\text { Conflicts of } \\
\text { interest in } \\
\text { breastfeeding }\end{array}$ & $\begin{array}{l}\text { Breastfeeding is the most important } \\
\text { preventive interventions for reducing } \\
\text { deaths for under fives, }{ }^{18} \text { yet breastfeeding } \\
\text { rates are declining. One important reason } \\
\text { is the continued extensive marketing by } \\
\text { the Infant Food Industry (IFI), }{ }^{19} \text { despite } \\
\text { the development of the WHO } \\
\text { International Code of Marketing of Breast } \\
\text { milk substitutes in } 1981{ }^{20} \text { The key } \\
\text { provisions of the code are: no advertising } \\
\text { of products, no free samples, no } \\
\text { promotion of products in health care } \\
\text { facilities nor free or low cost supplies, no } \\
\text { gifts or samples to health care workers, } \\
\text { accurate labelling of products and } \\
\text { information explaining the benefits of } \\
\text { breastfeeding. Unfortunately, violations of } \\
\text { the Code continue. }{ }^{21} \\
\text { Sponsorship of health professionals, in } \\
\text { particular doctors, is widespread and } \\
\text { many educational meetings would not } \\
\text { happen without the support of the IFI. } \\
\text { This creates a conflict of interest contrary } \\
\text { to World Health Assembly Resolution } \\
58.32 \text { which states that we must 'ensure } \\
\text { that financial support and other incentives }\end{array}$ & $\begin{array}{l}\text { The International Society for Social } \\
\text { Pediatrics and Child Health } \\
\text { (ISSOP) developed a position } \\
\text { statement on sponsorship, in which } \\
\text { recommendations were made for } \\
\text { paediatric associations. }{ }^{23} \text { They } \\
\text { worked closely with the voluntary } \\
\text { sector to educate paediatricians, } \\
\text { build alliances in support of } \\
\text { breastfeeding, and demonstrate } \\
\text { alternatives means of subsidising } \\
\text { paediatric education. It became } \\
\text { clear that many paediatric } \\
\text { associations are closely involved } \\
\text { with IFI and the pharmaceutical } \\
\text { industry and persistent robust } \\
\text { advocacy will be required to build } \\
\text { sufficient opposition to this conflict } \\
\text { of interest. The report is being used } \\
\text { to lobby for change. }\end{array}$ \\
\hline
\end{tabular}




\begin{tabular}{|l|l|l|}
\hline & $\begin{array}{l}\text { for programmes and health professionals } \\
\text { working in infant and young-child health } \\
\text { do not create conflicts of interest'. Such } \\
\text { conflict of interest is likely to benefit the } \\
\text { industry because firstly, they will only } \\
\text { pay out large sums of money if they feel } \\
\text { that this will result in increased sales, and } \\
\text { secondly, there is abundant evidence from } \\
\text { pharmaceutical sponsorship that giving } \\
\text { money to doctors increases the } \\
\text { prescribing of the drugs concerned. }\end{array}$ & \\
\hline
\end{tabular}

Table 1: Examples of advocacy to improve child health

\section{SUMMARY}

As child health specialists, advocacy is incumbent on all of us to observe and enforce the maintenance of childrens' rights. We have a duty of care to the children who we care for and also the whole population. Supporting the views of children and parents, alongside other professionals, we can make lasting improvements in child health.

\section{COMPETING INTERESTS}

Nil

\section{FUNDING}

There was no specific funding for this work. DD's academic post is funded by NIHR.

\section{REFERENCES}

1. Liu L, Oza S, Hogan D, et al. Global, regional, and national causes of child mortality in 2000-13, with projections to inform post-2015 priorities: an updated systematic analysis. Lancet 2015;385(9966):430-40.

2. Asada Y, Hurley J, Norheim OF, et al. Unexplained health inequality - is it unfair? Int $\mathbf{J}$ Equity Health 2015;14(1):11.

3. Malqvist M. Abolishing inequity, a necessity for poverty reduction and the realisation of child mortality targets. Arch Dis Child 2015;100 Suppl 1:S5-9.

4. Scully P, Reid O, Macken A, et al. Food and beverage cues in UK and Irish childrentelevision programming. Arch Dis Child 2014;99(11):979-84.

5. Waterston T. Teaching and learning about advocacy. Archives of disease in childhood Education and practice edition 2009;94(1):24-8. 
6. UNICEF Innocenti Research Centre. Building Child Friendly Cities. A Framework for Action: UNICEF,, 2004.

7. Webster J, Dunford E, Kennington S, et al. Drop the Salt! Assessing the impact of a public health advocacy strategy on Australian government policy on salt. Public health nutrition 2014;17(1):212-8.

8. Reisman J, Gienapp A, Stachowiak S. A Guide to Measuring Advocacy and Policy. The Evaluation Exchange 2007;13:22-23.

9. McDougall L, Sharma A, Franz-Vasdeki J, et al. Prioritising women's, children's, and adolescents' health in the post-2015 world. BMJ 2015;351:h4327.

10. American Academy of Pediatrics. AAP Agenda for Children Strategic Plan Poverty and Child Health. Secondary AAP Agenda for Children Strategic Plan Poverty and Child Health 2015. https://www.aap.org

11. Gosling L, Cohen D. Advocacy Matters: Helping children change their world: The International Save the Children Alliance, 2007.

12. Council for Diabled Children. Secondary Council for Diabled Children 2015. http://www.councilfordisabledchildren.org.uk/what-we-do/work-themes/participation.

13. Klein M, Vaughn LM. Teaching social determinants of child health in a pediatric advocacy rotation: small intervention, big impact. Med Teach 2010;32(9):754-9.

14. Department of Health. Protecting children from secondhand smoke and nicotine addiction. Secondary Protecting children from secondhand smoke and nicotine addiction 2014. https://www.gov.uk/government/news/protecting-children-from-secondhand-smokeand-nicotine-addiction.

15. Action on Smoking and Health. Secondhand Smoke: the impact on children, 2014.

16. Contact a family. Counting the Costs 2014, 2014.

17. British Association for Community Child Health, British Academy of Childhood Disability. Impact of austerity measures on families with disabled children, 2014.

18. Jones G, Steketee RW, Black RE, et al. How many child deaths can we prevent this year? The Lancet;362(9377):65-71.

19. UNICEF. Breastfeeding on the Worldwide Agenda, 2013.

20. World Health Organisation. Code of Marketing of Breastmilk Substitutes. Geneva, 1981.

21. International Baby Food Action Network. Cracking the Code 2014.

22. Wazana A. Physicians and the pharmaceutical industry: is a gift ever just a gift? JAMA 2000;283(3):373-80.

23. International Society for Social Pediatrics and Child Health. Position Statement on Sponsorship of paediatricians by the Babyfood Industry. 2014.

\section{Figure 1: The Advocacy Cycle- A framework for planning an advocacy strategy ${ }^{11}$}

Reproduced with permission from Save the Children UK. 